\title{
Chemical Composition of the Essential Oils of Lavanda Cultivated in Herzegovina
}

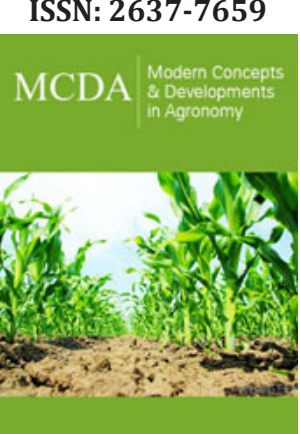

*Corresponding author: Aleksandra Govedarica-Lučić, Univerzitet Istočno Sarajevo, Poljoprivredni fakultet, Vuka Karadžića 30, Bosnia and Hercegovina

Submission: 海 September 21, 2021

Published: 倫 November 15, 2021

Volume 9 - Issue 5

How to cite this article: Aleksandra Govedarica Lučić, Malešević Zoranka, Ivana Bošković, Slobodanka Popović. Chemical Composition of the Essential Oils of Lavanda Cultivated in Herzegovina. Mod Concep Dev Agrono. 9(5). MCDA. 000721. 2021 DOI: 10.31031/MCDA.2021.09.000721

Copyright@ Aleksandra Govedarica Lučić. This article is distributed under the terms of the Creative Commons Attribution 4.0 International License, which permits unrestricted use and redistribution provided that the original author and source are credited.

\author{
Aleksandra Govedarica Lučić1*, Malešević Zoranka ${ }^{1}$, Ivana Bošković ${ }^{1}$ and \\ Slobodanka Popović ${ }^{2}$ \\ ${ }^{1}$ Univerzitet Istočno Sarajevo, Poljoprivredni fakultet, Vuka Karadžića 30, Bosnia and \\ Hercegovina \\ ${ }^{2}$ Ljekobilje Hercegovina, Crnogorski put bb, Ljubinje, Bosnia and Hercegovina
}

\begin{abstract}
In this study, we analyzed the chemical composition of essential oils of two types of lavender cultivated in Herzegovina. Lavender essential oil was isolated by hydro distillation. Chemical characterization of individual components of essential oil was performed by gas chromatography GC-MS. The most ingredients of essential oil of Lavanda angustifolia are linalool (28.01\%), linalyl acetate (27.59\%), cis- $\beta$ ocimene (5.05), trans $\beta$-ocimene (4.09), terpinene-4-ol (4.86), lavandulyl acetate (5.90) i $\beta$-caryophyllene (3.93). The most ingredients of essential oil of Lavanda sp are: linalool (34.76\%), linalyl acetate (27.59\%), 1.8-cineole (3.21), camphor (6.93), borneol (4.05), $\alpha$-terpineol (2.49), terpinene-4-ol (3.21), lavandulyl acetate (2.83) i $\beta$-caryophyllene (2.28).
\end{abstract}

Keywords: Lavender; Essential oil; Chemical composition

\section{Introduction}

Lavender is a perennial, aromatic plant from family Lamiaceae. It is used in medicine, food and cosmetics industry. Lavender is a plant of the Mediterranean region. It is produced in all areas with favorable conditions. Due to high temperatures, stony soil and a large number of sunny days, the area of Eastern Herzegovina provides ideal conditions for growing lavender. However, due to some ecological modification and adaptation of this species, lavender plantations can be found in continental areas, as well as at higher altitudes [1].

To date, 48 different species of lavender have been described. However, only the essential oil of Lavandula angustifolia, Lavandula latifolia and Lavender hybrid is used in the cosmetic industry [2]. Lavender essential oil contains about 100 active ingredients. The main ingredients of lavender essential oil are linalyl acetate and linalool. True lavender essential oil contains about $35-60 \%$ esters marked in linalyl acetate, while hybrid lavender essential oil contains only $7-16 \%$ esters [3].

Lavender essential oil is an excellent sedative, it has an effect on reducing bloating. It is often used as a corrector of the smell and taste of pharmaceutical preparations [1]. A large number of previous studies have confirmed that lavender essential oil has antioxidant, antimicrobial, anti-inflammatory properties [4-6]. Lavender essential oil is a mixed of chemical compounds with different antimicrobial properties. The antimicrobial effect of lavender essential oil depends on several active ingredients. Pharmacological and clinical evidence shows that the rational use of lavender essential oil works in chronic emotional disturbance [7]. Numerous authors have confirmed that lavender essential oil has a high inhibitor of cholinesterase activity $[8,9]$.

Demand for lavender essential oil is on the rise, so lavender cultivation has been expanding over the past few years. The aim of this research is the chemical characterization of lavender essential oils from the area of eastern Herzegovina. 


\section{Material and Methods}

\section{Plant material}

Plant material was collected in the phenophase of flowering in June 2020 in the area of Ljubinje in eastern Herzegovina. The plant material was dried in the shade on a draft. The dried plant material is packed in paper bags and stored in a dry and cool place.

\section{Oil extraction}

The essential oil was extracted by hydro distillation of dried plant material in a Clevenger apparatus according to the procedure prescribed by Ph. South. V [10]. During hydro distillation, the proportional ratio of plant material and water was 1:10 (m / v). The hydro distillation lasted for two hours. Extracted essential oil is a light yellow or colorless easily volatile liquid, with a pleasant smell, spicy and bitter taste. The results of determining the content of essential oil in the herb L. angustifolia represent the mean value of three comparative determinations.

\section{Gas chromatography}

We used a gas chromatograph HP 5890 with flame ionizing detector (FID), a column with HP-5MS stationary phase $(25 \mathrm{~m} x$ $0.32 \mathrm{~mm} \times 0.52 \mathrm{~mm}$ ) and an HP-GCD system with a column of the same polarity. Helium (chromatographic quality) was a carrier gas with rate of working of $1 \mathrm{ml} / \mathrm{min}$. Samples were analyzed in a splitless injector) (1:50).

The temperature of the injector was $250^{\circ} \mathrm{C}$, the detector $280^{\circ} \mathrm{C}$, and the column temperature was linearly programmed from $40{ }^{\circ} \mathrm{C}$ to $280{ }^{\circ} \mathrm{C} ; 4{ }^{\circ} \mathrm{C} / \mathrm{min}$. Component identification was performed by comparing peak retention times with standard samples and their mass spectra, and by comparing the mass spectra of components with Wiley275 library data. The retention times of the determined components are correlated with the values of the Kovačević index for the DB-5 column, according to the data from the R. Adams spectrum library. The content of the components is given as the value of the percentage of areas (area\%) obtained by integrating the peaks using FID detectors.

\section{Climatic characteristics of the studied area}

The study area is characterized by a sub-Mediterranean climate with mild winters and warm summers. The maximum temperature in summer is around $40^{\circ} \mathrm{C}$, while the minimum temperature in winter is around $-5^{\circ} \mathrm{C}$. During the year, on average, about $1950 \mathrm{~mm}$ of rain falls. In the geomorphological sense, the Ljubinje field is a typical karst field with a flat terrace. The experimental plot is a soil of neutral reaction, rich in nitrogen content, very rich in easily accessible phosphorus and very rich in potassium (Table 1).

Table 1: Land characteristics of the study area.

\begin{tabular}{|c|c|c|c|}
\hline $\mathbf{p H}$ in $\mathbf{1 M} \mathbf{~ K C l}$ & (N) $\%$ & $\mathbf{m g ~ K}_{2} \mathbf{0} / \mathbf{1 0 0 g}$ soil & mg $\mathbf{P}_{\mathbf{2}} \mathbf{O}_{5} / \mathbf{1 0 0 g}$ \\
\hline 6,91 & 0,28 & 74,6 & 50,6 \\
\hline
\end{tabular}

\section{Research Results with Discussion}

Analysis of lavender essential oils indicated a variety of chemical components. The most common components of Lavender angustifolia essential oil were oxidized terpenes: linalool (28.01\%) and linalyl acetate (27.59\%). Other Less common components are: cis- $\beta$-ocimene $(5.05 \%)$, trans $\beta$-ocimene $(4.09 \%)$, terpinene- 4 -ol (4.86\%), lavandulyl acetate $(5.90 \%)$ and $\beta$-caryophyllene $(3.93 \%)$. The results of our research are in accordance with the results of the research [11,12]. In the research of Bialon et al. [13], in Poland, a significantly higher percentage $(41.8 \%)$ of linalool and linalyl acetate $(32.7 \%)$ was identified. Different percentages of linalool, linalyl acetate and other constituents are probably due to different climatic conditions, which is in accordance with the research Stepić [11]. The author states that variations in the quantitative content of components are influenced by external factors. Kišgeci et al. [3] in their paper they conclude that variations in the quantitative content of components are influenced by external factors (Table 2).

Table 2: Chemical composition of essential oil in Lavandula angustifolia.

\begin{tabular}{|c|c|c|c|}
\hline No. & RT & Compound & $\%$ of Compound of L. angustifolia \\
\hline 1 & 5.905 & n.d. & 0.6058 \\
\hline 2 & 7.131 & $\alpha$-thujene & 0.18303 \\
\hline 3 & 7.319 & $\alpha$-pinene & 0.31351 \\
\hline 4 & 7.714 & Camphene & 0.15919 \\
\hline 5 & 8.34 & $\beta$-pinene & 0.0868 \\
\hline 6 & 8.5 & octen-3-ol & 0.41237 \\
\hline 7 & 8.66 & n.d. & 0.82172 \\
\hline 8 & 8.765 & Myrcene & 1.64012 \\
\hline 9 & 8.889 & n.d. & 0.25061 \\
\hline 10 & 9.194 & n.d. & 0.09129 \\
\hline 11 & 9.383 & $\alpha$-phellandrene & 0.92948 \\
\hline 12 & 9.54 & n.d. & 0.10575 \\
\hline
\end{tabular}




\begin{tabular}{|c|c|c|c|}
\hline 13 & 9.702 & n.d. & 0.9806 \\
\hline 14 & 9.787 & p-cimene & 0.28842 \\
\hline 15 & 9.907 & Limonene & 1.3912 \\
\hline 16 & 10.001 & 1.8-cineole & 1.08943 \\
\hline 17 & 10.125 & cis- $\beta$-ocimene & 5.04869 \\
\hline 18 & 10.443 & trans- $\beta$-ocimene & 4.09117 \\
\hline 19 & 10.796 & $\gamma$-terpinene & 0.29329 \\
\hline 20 & 11127 & n.d. & 0.06079 \\
\hline 21 & 11.258 & linalool oxide trans & 0.07936 \\
\hline 22 & 11.719 & linalool oxide cis & 0.20992 \\
\hline 23 & 12.217 & Linalool & 28.01053 \\
\hline 24 & 12.409 & octenyl acetate & 1.42674 \\
\hline 25 & 12.799 & n.d. & 0.076 \\
\hline 26 & 12.975 & Camphor & 1.06412 \\
\hline 27 & 13.572 & n.d. & 0.51063 \\
\hline 28 & 14.279 & Borneol & 2.52104 \\
\hline 29 & 14.658 & terpinene-4-ol & 4.86248 \\
\hline 30 & 14.814 & n.d. & 0.07166 \\
\hline 31 & 14.95 & Lavandulol & 0.80402 \\
\hline 32 & 15.081 & $\alpha$-terpineol & 0.91159 \\
\hline 33 & 16.236 & n.d. & 0.22312 \\
\hline 34 & 16.655 & n.d. & 0.12202 \\
\hline 35 & 17.125 & linalyl acetate & 27.59798 \\
\hline 36 & 18.155 & lavandulyl acetate & 5.90925 \\
\hline 37 & 20.418 & neryl acetate & 0.49852 \\
\hline 38 & 20.844 & n.d. & 0.63338 \\
\hline 39 & 21.008 & geranyl acetate & 0.93966 \\
\hline 40 & 22.005 & n.d. & 0.04988 \\
\hline $41 .$. & 22.21 & $\beta$-caryophyllene & 3.92367 \\
\hline 42 & 22.605 & trans- $\beta$-bergamotena & 0.1416 \\
\hline 43 & 22.19 & trans- $\beta$-farnesene & 1.73859 \\
\hline 44 & 24.016 & n.d. & 0.56586 \\
\hline 45 & 26.951 & caryophyllene oxide & 0.26286 \\
\hline
\end{tabular}

The most common components of essential oil in Lavandula $s p$. were linalool $(34.76 \%)$ and linalyl acetate $(27.59 \%)$, and the less represented components were 1.8-cineole (3.21), camphor (6.93), borneol (4.05), $\alpha$-terpineol (2.49), terpinene-4-ol 3.21), lavandulyl acetate (2.83) and $\beta$-caryophyllene (2.28). The same components with a similar percentage were found in both types of lavender (Lavandula angustifolia, Lavandula sp.). Similar results are published by other authors [11,14-16]. Different results are published by Maskovic et al. [17]. They found a significantly higher percentage of linalool (54.24\%) and a very low percentage of linalyl acetate $(0.77 \%)$ in lavender essential oil (Table 3).

Table 3: Chemical composition of essential oil in Lavandula sp.

\begin{tabular}{|c|c|c|c|}
\hline No. & RT & Compound & \% of Compound \\
\hline 1 & 7.139 & $\alpha$ - thujene & 0.04039 \\
\hline 2 & 7.326 & $\alpha$-pinene & 0.32852 \\
\hline 3 & 7.719 & Camphene & 0.1784 \\
\hline 4 & 8.346 & $\beta$-pinene & 0.05371 \\
\hline 5 & 8.454 & octen-3-ol & 0.43099 \\
\hline 6 & 8.769 & Myrcene & 1.53083 \\
\hline
\end{tabular}




\begin{tabular}{|c|c|c|c|}
\hline 7 & 9.366 & $\alpha$-phellandrene & 0.13017 \\
\hline 8 & 9.546 & $\alpha$-terpinene & 0.05819 \\
\hline 9 & 9.792 & p-cimene & 0.455 \\
\hline 10 & 9.903 & limonene & 0.78147 \\
\hline 11 & 10.01 & 1.8-cineole & 3.20934 \\
\hline 12 & 10.119 & cis- $\beta$-ocimene & 0.93665 \\
\hline 13 & 10.439 & trans- $\beta$-ocimene & 0.88457 \\
\hline 14 & 10.801 & $\gamma$-terpinene & 0.13978 \\
\hline 15 & 11.261 & linalool oxide trans & 0.0852 \\
\hline 16 & 11.721 & linalool oxide cis & 0.41507 \\
\hline 17 & 12.241 & linalool & 34.75992 \\
\hline 18 & 12.309 & n.d. & 0.14046 \\
\hline 19 & 12.409 & octenyl acetate & 0.27597 \\
\hline 20 & 12.979 & n.d. & 0.2245 \\
\hline 21 & 13.61 & camphor & 6.92804 \\
\hline 22 & 14.32 & borneol & 4.04786 \\
\hline 23 & 14.653 & terpinene-4-ol & 3.20865 \\
\hline 24 & 14.97 & lavandulol & 0.25599 \\
\hline 25 & 15.094 & $\alpha$-terpineol & 2.4968 \\
\hline 26 & 16.555 & n.d. & 0.44502 \\
\hline 27 & 17.115 & n.d. & 0.09913 \\
\hline 28 & 17.115 & linalyl acetate & 23.09242 \\
\hline 29 & 18.139 & lavandulyl acetate & 2.82501 \\
\hline 30 & 19.388 & n.d. & 0.10266 \\
\hline 31 & 20.42 & neryl acetate & 0.84971 \\
\hline 32 & 21.014 & geranyl acetate & 1.64449 \\
\hline 33 & 21.232 & n.d. & 0.07557 \\
\hline 34 & 21.698 & n.d. & 0.09527 \\
\hline 35 & 22.201 & $\beta$-caryophyllene & 2.28564 \\
\hline 36 & 22.608 & trans- $\alpha$-bergamotena & 0.19789 \\
\hline 37 & 22.826 & n.d. & 0.05165 \\
\hline 38 & 22.19 & trans- $\beta$-farnesene & 1.50971 \\
\hline 39 & 23.417 & n.d. & 0.14769 \\
\hline 40 & 23.661 & n.d. & 0.11806 \\
\hline 41 & 24.018 & n.d. & 0.93373 \\
\hline 42 & 24.537 & n.d. & 0.10174 \\
\hline 43 & 24.727 & n.d. & 0.88619 \\
\hline 44 & 24.958 & n.d. & 0.40331 \\
\hline 45 & 25.19 & n.d. & 0.42248 \\
\hline 46 & 26.948 & caryophyllene oxide & 0.14409 \\
\hline 47 & 28.515 & n.d. & 0.64455 \\
\hline 48 & 29.625 & n.d. & 1.29699 \\
\hline
\end{tabular}

The quantitative composition of essential oils depends on the method of cultivation of lavender, altitude and microclimatic conditions $[18,19]$.

\section{Conclusion}

The analysis of lavender essential oils from the area of eastern
Herzegovina indicated the diversity of chemical constituents in them. The percentage of components was similar in both types of lavender. The most common components of the tested lavender essential oils are oxidized terpenes: linalool, linalyl acetate, cis$\beta$-ocimene, trans $\beta$-ocimene, terpinene-4-ol, lavandulyl acetate, $\beta$-caryophyllene, 1.8-cineole, camphor, borneol and $\alpha$-terne. 
Although there are data on the composition of lavender essential oils in the literature, the obtained results are significant in terms of evaluating the quality of essential oils of the tested species from the territory of Herzegovina.

\section{References}

1. Stepanović B, Radanović D (2007) Organic lavender production in Republika Srpska. Ljekobilje, Trebinje, Bosnia and Herzegovina, pp: $1-44$.

2. Lubbe A, Verpoorte R (2011) Cultivation of medicinal and aromatic plants for specialty industrial materials. Industrial Crops and Products 34(1): 785-801.

3. Kišgeci J, Jelačić S, Beatović D (2009) Medicinal, aromatic and spicy herbs. Faculty of Agriculture, University of Belgrade, Serbia.

4. Romeo FV, De Luca S, Piscopo A, Poiana M (2008) Antimicrobial effect of some essential oils. J Essent Oil Research 20(4): 373-379.

5. Woronuk G, Demissie Z, Rheault M, Mahmoud S (2011) Biosynthesis and therapeutic properties of Lavandula essential oil constituents. Planta Med 77(1): 7-15.

6. Carrasco A, Martinez Gutierrez R, Tomas V, Tudela J (2015) Lavandula angustifolia and Lavandula latifolia essential oils from spain: Aromatic profile and bioactivities. Planta Medica 82(1-2): 163-170.

7. Abuhamdah S, Chazot PL (2008) Lemon balm and lavender herbal essential oils: old and new ways to treat emotional disorders. Current Anaesthesia \& Critical Care 19(4): 221-226.

8. Ali Shtayeh MS, Abu Zaitoun SY, Dudai N, Jamous RM (2020) Downy lavender oil: A promising source of antimicrobial, antiobesity, and antialzheimer's disease agents. Evid Based Complementary Alternat Med 2020: 5679408.

9. Al Sarar AS, Hussein HI, Abobakr Y, Bayoumi AE, Al Otaibi MT (2014) Fumigant toxicity and antiacetylcholinesterase activity of Saudi Mentha longifolia and Lavandula dentata species against Callosobruchus maculatus (F.) (Coleoptera: Bruchidae). Turk Entomol Derg 38(1): 1118.

10. Adams PR (2007) Identification of essential oil components by gas chromatography/ mass spectrometry, ( $4^{\text {th }}$ edn), Allured Publishing Corp, Carol Stream, IL 60188, USA.

11. Stepić K (2017) Analysis of volatile constituents of the plant species Lavandula angustifolia. Master thesis. University of Nis. Serbia.

12. Dong G, Bai X, Aimila A, Aisa HA, Maiwulanjiang M (2020) Study on lavender essential oil chemical compositions by GC-MS and improved pGC. Molecules 25(14): 1-8.

13. Biało M, Krzysko Łupicka T, Nowakowska Bogdan E, Wieczorek PP (2019) Chemical composition of two different lavender essential oils and their effect on facial skin microbiota. Molecules 24(18): 3270.

14. Smigielski K, Raj A, Krosowiak K, Gruska R (2009) Chemical composition of the essential oil of Lavandula angustifolia cultivated in Poland. Journal of Essential Oil-Bearing Plants 12(3): 338-347.

15. Stanković N, Čomić Lj R, Kocić BD, Nikolić DM, Mihajilov Krstev T, et al. (2011) Hemijska Industrija 65(5): 583-589.

16. Gharib FA, Badr SEA, Al Ghazali BAS, Zahran MK (2013) Chemical composition, antioxidant and antibacterial activities of lavender and marjoram essential oils. Egypt J Chem 56(1): 1-24.

17. Mašković P, Đurović S, Radojković M, Cvetanović A, Veličković V, et al. (2017) Isolation and chemical profile of Thymus serpyllum L. and Lavandula angustifolia Mill. Esential oils. XXII Conference on biotechnology, pp: 541-548.

18. Cavanagh HMA, Wilkinson JM (2005) Lavender essential oil: a review. Aust Infec Control 10(1): 35-37.

19. Bouzouita N, Kachouri F, Hamdi M, Chaabouni MM, Ben Aissa R, et al. (2005) Volatile constituents and antimicrobial activity of Lavandula stoechas L. oil from Tunisia. J Essent Oil Res 17(5): 584-586.

For possible submissions Click below: 